\title{
CURTOBACTERIUM FLACCUMFACIENS PV. FLACCUMFACIENS DETECTION IN BEAN SEEDS USING A SEMI-SELECTIVE CULTURE MEDIUM
}

\author{
Antonio Carlos Maringoni*; Renata de Cassia Camara \\ UNESP - São Paulo State University, Faculty of Agronomy, Crop Production Department, State of São Paulo, Brazil \\ Submitted: March 20, 2006; Returned to authors for corrections: May 15, 2006; Approved: October 06, 2006
}

\begin{abstract}
The bacterial wilt caused by Curtobacterium flaccumfaciens pv. flaccumfaciens is currently considered one of the most important bacterial bean disease in Brazil. One of the most effective control methods against this disease is the use of healthy seeds. However, no methods are known that could be routinely used to detect this bacterium in bean seeds under Brazilian condition. The aim of this work was to evaluate qualitative and quantitative detection methods for Curtobacterium flaccumfaciens pv. flaccumfaciens in naturally-infected bean seeds, and the detection of this pathogen in thirty bean seed samples, by sowing onto a semi-selective culture medium the leachate obtained from soaked bean seeds. Both the qualitative and quantitative methods were effective for detecting the presence of the bacteria in the seeds samples analysed. The qualitative method proved more practical for rotine use; of the thirty bean seed samples analyzed by this method, fifty percent were infected with Curtobacterium flaccumfaciens pv. flaccumfaciens.
\end{abstract}

Key words: bacterial wilt, isolation, seed pathology, Phaeolus vulgaris

\section{INTRODUCTION}

Bean bacterial wilt, caused by Curtobacterium flaccumfaciens pv. flaccumfaciens (Cff), was first described in the USA in 1921 by Hedges (6), causing serious problems to the crop. This disease occurs in several European countries, as well as in Australia, Canada, Mexico, and Colombia (2). In Brazil, bacterial wilt has been verified in several regions resulting in loses in bean production $(8,9,18)$.

Typical symptoms of the disease in bean plants are mainly wilting, vascular darkening, and death of the above-ground part of the plant (7). Under field conditions during mildtemperature seasons infected bean plants have developed that lack bacterial disease symptoms. This fact has been observed by Thomas and Graham (17), who isolated Xanthomonas axonopodis pv. phaseoli and Cff from bean plant stems without external symptoms. Other plants, in addition to beans, have been reported as Cff hosts including pea, soybean, Phaseolus lunatus, Lupinus polyphyllus, Vigna cylindrica, $V$. sesquipedalis, Dolichos labllab, Phaseolus radiatus, $P$. lathyroides, $P$. calcaratus, and $P$. acutifolius $(7,15)$.

In bean plants, some control measures are employed against bacterial wilt include the use of healthy seeds, since Cff survives and is transmitted by seed $(13,15)$. Burkholder (3) verified that Cff survived for 24 years in bean seeds stored under natural environmental conditions.

In practice, few methods are described in the literature for Cff detection in bean seeds. The European and Mediterranean Plant Protection Organization recommends a visual examination of seeds, direct or indirect isolation of the bacterium, and a serum test for Cff detection in bean seeds for quarantine purposes (4). In Japan, again for quarantine purposes Mizuno (11) and Mizuno and Kawai (12) recommended the isolation of Cff from bean seeds in semi-selective culture media, which use specific carbon sources and antimicrobial agents, together with serum tests but these media are very expensive for routine use in Brazil (10). Tegli et al. (16) developed specific primers for Cff that can be used for

*Corresponding Author. Mailing address: UNESP - Faculdade de Ciências Agronômicas de Botucatu, Departamento de Defesa Fitossanitária. Setor de Defesa Fitossanitária - Fazenda Experimentla Lageado 18603-970 - Botucatu, SP - Brasil - Caixa-Postal: 237. Tel.: (14) 3811-7205 ou (14) 38117206. E-mail: maringoni@fca.unesp.br 
detection of this bacterium in naturally-infected bean seeds, by the PCR technique.

Considering the necessity for the development of a practical, effective, and low-cost method for the routine analysis of bean seeds in Brazil, the present work was carried out using Cff isolation in a semi-selective culture medium developed for this purpose (10).

\section{MATERIALAND METHODS}

Comparison of methods for Curtobacterium flaccumfaciens pv. flaccumfaciens detection in bean seeds

Quantitative and qualitative Cff analysis were carried out in six $200 \mathrm{~g}$ samples of bean seeds (approximately 1,000 seeds), cultivar Campeão II, from commercial field where the occurence of bacterial wilt was verified. Each sample containing $200 \mathrm{~g}$ of seeds was soaked in $600 \mathrm{~mL}$ distilled and sterilized water for $24 \mathrm{~h}$, under refrigeration $\left(5^{\circ} \mathrm{C}\right)$. Following soaking, the seeds were manually stirred in flasks and the leachate liquid was sampled. For the quantitative analyse, $100 \mu \mathrm{L}$ of the leach liquid obtained from the seeds and their dilutions $\left(10^{-1}, 10^{-2}\right.$, and $\left.10^{-3}\right)$ were sown onto the surface of CFFSM culture medium (10) with the aid of a Drigalski spatula. Four Petri dishes were sown for each concentration. In the qualitative evaluation, however, the seed leachate (same of quantitative analysis) was sown by streaking with a loop onto the surface of the CFFSM semi-selective culture medium. Four Petri dishes were sown, in two halves per each plate, totaling eight halves.

The Petri dishes remained under incubation at $28-30^{\circ} \mathrm{C}$, for 96 to $120 \mathrm{~h}$, and colonies with cultural characteristics resembling Cff (colonies circular shape, with yellow to slighty orangish coloration; casein hydrolisis and slight fading of dye arround the colonies) were compared against the growth of a pure standard isolate (Feij-2634). Six bacterial isolates from each seed sample were selected for identification.

\section{CFFSM semi-selective culture medium}

This medium consisting of peptone - $5 \mathrm{~g}$, meat extract $-3 \mathrm{~g}$, sucrose - 5g, agar - 15g, skim milk powder* - 5g, Congo red* $0.05 \mathrm{~g}$, chlorothalonil* $-0.01 \mathrm{~g}$, thiophanate methyl* $-0.01 \mathrm{~g}$, nalidixic acid* - $0.01 \mathrm{~g}$, nitrofurantoin* - $0.01 \mathrm{~g}$, oxacillin* $0.001 \mathrm{~g}$, sodium azide* $-0.001 \mathrm{~g}$, and distilled water q.s. $1 \mathrm{~L}$, *added after autoclaving the basal medium, according Maringoni et al. (10).

\section{Curtobacterium flaccumfaciens pv. flaccumfaciens isolation in naturally infected bean seeds}

Thirty seed samples from several regions of Brazil were analized for the presence of Cff. Twenty-two samples were analyzed twice, and eight samples were analyzed once. Five $200 \mathrm{~g}$ subsamples were evaluated for each seed sample. Each subsample was transferred into a flask containing $600 \mathrm{~mL}$ distilled and sterilized water. The seeds were left in soaking for
$24 \mathrm{~h}$, under refrigeration. After soaking, the seeds were manually stirred and the resulting suspension was plated by streaking on Petri dishes containing CFFSM culture medium. Four Petri dishes were sown for each $200 \mathrm{~g}$ subsample, in two halves per each plate, totaling eight halves per subsample. The Petri dishes remained under incubation for a variable period between 96 and $120 \mathrm{~h}$, at $28-30^{\circ} \mathrm{C}$. After incubation, observations were made for bacterial colonies that showed cultural characteristics which resembled Cff when compared with a pure standard isolate (Feij2634). A given seed sample was considered to carry Cff when Cff growth was observed in at least one of the eight sown fields. Two to four bacterial isolates from each positiv sample were selected to be submitted for identification.

\section{Identification of bacterial isolates obtained from seeds}

Cff-suspected bacterial colonies were initially purified in a nutrient sucrose-agar medium (NSA) containing sodium chloride at $7 \%$, and evaluated using Gram-staining, $\mathrm{KOH}$ test, pathogenicity test in cultivar Pérola bean plants, and identification by the Biolog ${ }^{\circledR}$ method (Biolog, Hayward, USA) previous described by Maringoni et al. (10).

\section{RESULTS AND DISCUSSION}

The presence of Cff in the bean seeds analyzed was observed, regardless of the method used quantitative or qualitative (Table 1). Both methods were effective to isolate Cff-suspected colonies in the seeds. All isolates were identified as Cff by the Biolog $®$ method, regardless of their pathogenicity (Table 1). Three Cff isolates were not pathogenic to bean plants.

The analysis of thirty bean seed samples from several localities in Brazil revealed that fifty percent of them were infected with Cff (Table 2). All suspected bacterial isolates were identificated as Cff, by the Biolog ${ }^{\circledR}$ method. Seven out of the ninety-seven bacterial isolates submitted to the pathogenicity test were non-pathogenic to Cultivar Pérola bean plants (Table 2). All suspected isolates showed cultural characteristics similar to Cff on the CFFSM culture medium (yellow colonies and the presence of casein hydrolysis and Congo red fading) Figure 1, and grew in NSA medium containing sodium chloride at $7 \%$, were Gram-positive rods and did not form a string in the $\mathrm{KOH}$ test.

Although a specific standard method for Cff detection in bean seeds does not exist in Brazil, especially for routine analysis, the methodology herein employed was effective to isolate this bacterium from naturally-infected bean seeds. The method of plating on a semi-selective culture medium is used in the detection of a number of phytopathogenic bacteria in seeds of several crops, and usually the seed leachate dilutions, either concentrated or not by centrifugation, are sown onto specific culture media as, for example, Pseudomonas savastanoi pv. phaseolicola in bean seeds (19), Xanthomonas translucens pv. translucens in wheat seeds (14), and Clavibacter 
Table 1. Recovery of Curtobacterium flaccumfaciens pv. flaccumfaciens from bean seeds by two methods.

\begin{tabular}{|c|c|c|c|c|}
\hline \multirow{2}{*}{ Sample } & Quantitative method & Qualitative method & \multirow{2}{*}{$\begin{array}{c}\text { Pathogenicity } \\
\left(\mathrm{N}^{\text {o. }} \text { pathogenic isolates }\right. \\
\left./ \mathrm{N}^{o} \text { inoculated isolates }\right)\end{array}$} & \multirow{2}{*}{$\begin{array}{l}\text { Similarity index value } \\
\qquad(\text { Biolog } ®)^{\mathrm{a}}\end{array}$} \\
\hline & $\begin{array}{l}\text { Cff-suspected colonies } \\
\left.\text { (CFU.mL }{ }^{-1}\right)\end{array}$ & $\begin{array}{l}\mathrm{N}^{\circ} \text { fields containing Cff-suspected } \\
\text { colonies } / \mathrm{N}^{\circ} \text { fields sown }\end{array}$ & & \\
\hline $\mathrm{A}$ & $1.87 \times 10^{2} \pm 0,41$ & $1 / 8$ & $6 / 6$ & $0.710-0.844$ \\
\hline B & $1.39 \times 10^{4} \pm 0.28$ & $7 / 8$ & $5 / 6$ & 0.844 \\
\hline $\mathrm{C}$ & $7.48 \times 10^{4} \pm 0.26$ & $8 / 8$ & $6 / 6$ & $0.730-0.865$ \\
\hline $\mathrm{D}$ & $3.54 \times 10^{4} \pm 0.25$ & $8 / 8$ & $6 / 6$ & 0.844 \\
\hline $\mathrm{E}$ & $6.10 \times 10^{3} \pm 2.46$ & $7 / 8$ & $6 / 6$ & 0.860 \\
\hline $\mathrm{F}$ & $8.90 \times 10^{4} \pm 0.81$ & $8 / 8$ & $4 / 6$ & $0.775-0.810$ \\
\hline
\end{tabular}

${ }^{a}$ Range of the similarity index value of isolates compared against $C$. flaccumfaciens database.

Table 2. Recovery of Curtobacterium flaccumfaciens pv. flaccumfaciens from naturally-infected bean seeds collected from several localities in Brazil.

\begin{tabular}{|c|c|c|c|c|}
\hline Sample & $\begin{array}{l}\text { Locality } \\
\text { (State) }\end{array}$ & $\begin{array}{l}\text { Cff-suspected } \\
\text { isolates }^{\mathrm{a}}\end{array}$ & $\begin{array}{l}\text { Pathogenicity } \\
\text { (Path/inoc) }^{\mathrm{b}}\end{array}$ & $\begin{array}{l}\text { Similarity } \\
\text { index value } \\
(\text { Biolog® })^{\mathrm{c}}\end{array}$ \\
\hline F-1 & São Paulo & & & \\
\hline$A^{d}$ & & $+(1)$ & $3 / 3$ & $0.780-0.978$ \\
\hline B & & $+(1)$ & $3 / 3$ & $0.821-0.876$ \\
\hline F-3 & São Paulo & & & \\
\hline A & & $+(1)$ & $2 / 2$ & $0.876-0.926$ \\
\hline B & & $+(2)$ & $2 / 2$ & $0.844-0.943$ \\
\hline F-11 & São Paulo & & & \\
\hline A & & $+(4)$ & $4 / 4$ & $0.713-0.860$ \\
\hline B & & $+(5)$ & $3 / 4$ & $0.775-0.978$ \\
\hline F-12 & São Paulo & & & \\
\hline A & & $+(3)$ & $4 / 4$ & $0.756-0.876$ \\
\hline B & & $+(2)$ & $4 / 4$ & $0.735-0.926$ \\
\hline F-13 & São Paulo & & & \\
\hline A & & $+(3)$ & $3 / 3$ & $0.750-0.775$ \\
\hline B & & $+(4)$ & $4 / 4$ & $0.775-0.926$ \\
\hline F-15 & Paraná & & & \\
\hline A & & $+(3)$ & $3 / 3$ & $0.860-0.926$ \\
\hline B & & $+(3)$ & $3 / 3$ & $0.775-0.779$ \\
\hline F-19 & Paraná & & & \\
\hline A & & $+(5)$ & $5 / 5$ & $0.741-0.802$ \\
\hline B & & $+(5)$ & $5 / 5$ & $0.741-0.860$ \\
\hline F-20 & São Paulo & & & \\
\hline A & & $+(3)$ & $4 / 4$ & $0.659-0.741$ \\
\hline B & & $+(2)$ & $3 / 3$ & $0.730-0.738$ \\
\hline $\mathrm{F}-21$ & Paraná & & & \\
\hline A & & $+(2)$ & $3 / 4$ & $0.730-0.736$ \\
\hline B & & $+(5)$ & $2 / 4$ & $0.720-0.730$ \\
\hline
\end{tabular}

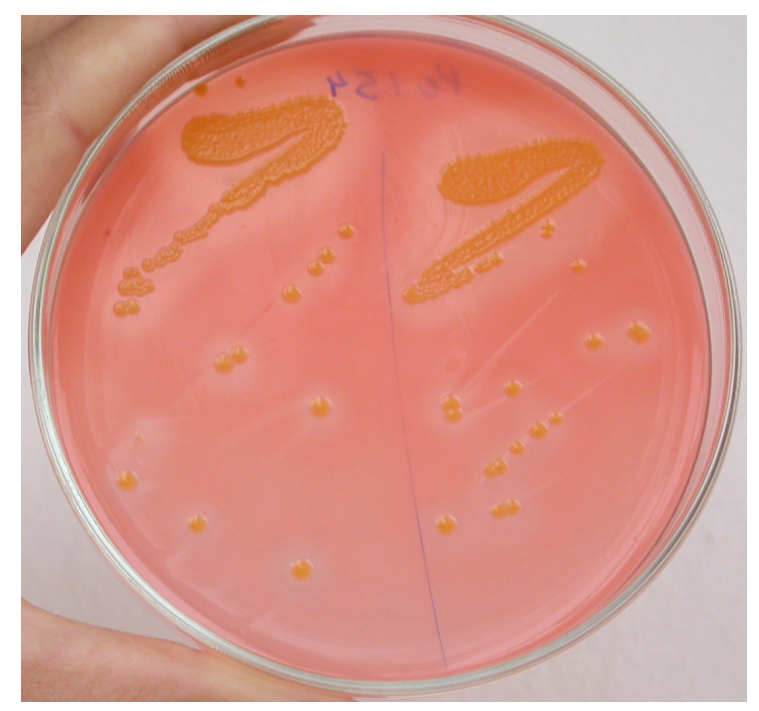

Figure 1. Cultural characteristics of Curtobacterium flaccumfaciens $\mathrm{pv}$. flaccumfaciens isolated from bean seeds on the CFFSM culture medium.

michiganensis subsp. michiganensis in tomato seeds (5). Although the literature does not contain references about the direct sowing of seed leachate suspensions by streaking onto the surface of the culture medium (qualitative analysis) in order to isolate phytobacteria in seeds, this procedure proved as viable, since the isolation of Cff from the seed samples analyzed was consistent.

It was verified the presence of Cff in fifty percent of the thirty seed samples analyzed from several regions of Brazil (Table 2). A lower number of seed samples infected by Cff was expected, but the results here obtained confirmed the widespread dissemination of this pathogen in several bean-producing regions in Brazil $(8,9,18)$. 


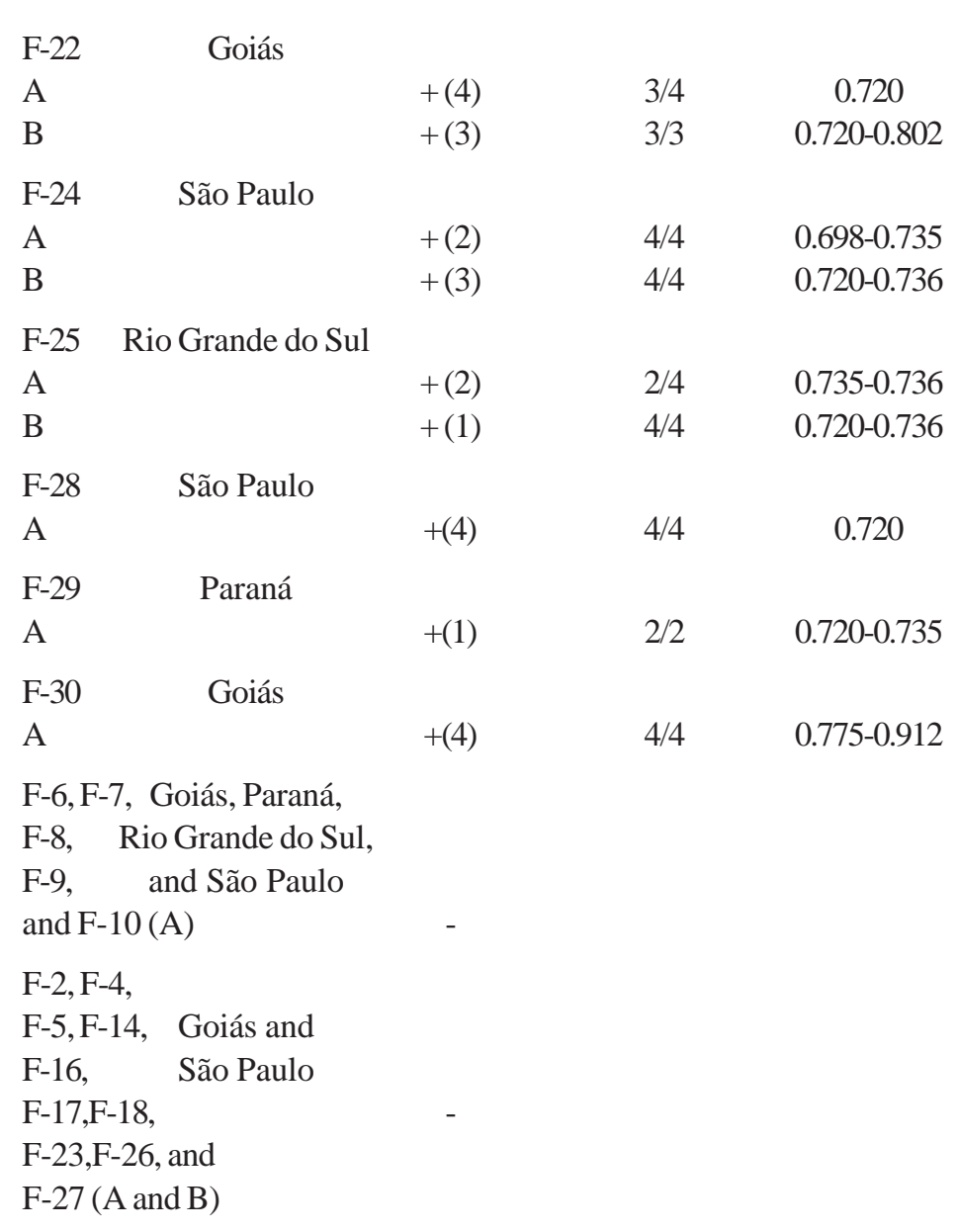

${ }^{\mathrm{a}}$ Number of subsamples containing Cff-suspected isolates; ${ }^{\mathrm{b}}$ Number of pathogenic isolates/number of inoculated isolates; 'Range of the similarity index value of isolates compared against $C$. flaccumfaciens database; ${ }^{\mathrm{d}} \mathrm{One}(\mathrm{A})$ or two (A and B) analysis.

\section{RESUMO}

\section{Detecção de Curtobacterium flaccumfaciens pv. flaccumfaciens em sementes de feijoeiro utilizando meio de cultura semi-seletivo}

Atualmente, a murcha-de-curtobacterium, causada por Curtobacterium flaccumfaciens pv. flaccumfaciens, é considerada uma das principais doenças baterianas da cultura do feijoeiro, no Brasil. Um dos métodos eficazes de controle desta doença é o emprego de sementes sadias. Entretanto, não se tem conhecimento de métodos que possam ser utilizados em rotina para o isolamento desta bactéria em sementes de feijoeiro. O presente trabalho teve por objetivo avaliar os métodos qualitativos e quantitativos de isolamento de Curtobacterium flaccumfaciens pv. flaccumfaciens em sementes de feijoeiro naturalmente infectadas e a detecção deste patógeno em trinta amostras de sementes de feijoeiro, pela semeadura do líquido de maceração das sementes em meio de cultura semi-seletivo. Tanto o método quantitativo quanto o quantitativo foram eficazes em detectar a presença da bactéria nas amostras de sementes analisadas. O método qualitativo mostrou-se mais prático para o uso em rotina e das trinta amostras de sementes de feijoeiro analisadas por este método cinqüenta porcento delas estavam infectadas com Curtobacterium flaccumfaciens pv. flaccumfaciens.

Palavras-chave: murcha-de-curtobacterium, isolamento, patologia de sementes, Phaeolus vulgaris

\section{REFERENCES}

The bacterial isolates submitted to the Biolog $₫$ test were identified as Cff. However, 7.5\% of the Cff isolates were nonpathogenic in the pathogenicity test. The non-pathogenicity of those isolates may be due to the mixture of both pathogenic and non-pathogenic Cff in the diseased bean plants, which would transmit them into their seeds, with the non-pathogenic strains having an endophytic status, similarly as Curtobacterium flaccumfaciens in citrus plants (1).

\section{ACKNOWLEDGEMENTS}

The authors express thanks for the financial support received from Fundação ao Amparo à Pesquisa do Estado de São Paulo (FAPESP), Conselho Nacional de Desenvolvimento Científico e Tecnológico (CNPq), and FUNDUNESP in the conduction of the present research.
1. Araujo, W.; Marcon, J.; Maccheroni, W.; van Elsas, J.D.; van Vuurd, J.W.L.; Azevedo, J.L. Diversity of endophytic bacterial population and their interaction with Xylella fastidiosa in citrus plant. Appl. Environ. Microbiol., 68: 4906-4814, 2002.

2. Brabury, J.F. Guide to plant pathogenic bacteria. CAB International Mycological Institute, Farhan House, 1986, 332p.

3. Burkholder, W.H. The longevity of the pathogens causing the wilt of the common bean. Phytopathology, 35: 743-744, 1945.

4. EPPO Curtobacterium flaccumfaciens pv. flaccumfaciens field inspection and seed-testing methods. Bulletin OEPP (EPPO), 24: 329-331, 1994.

5. Fatmi, M.; Schaad, N.W. Detection of Clavibacter michiganense subsp. michiganense in tomato seed. In: Saettler, A.W.; Schaad, N.W.; Roth, D.A. (ed.). Detection of Bacteria in Seed and Other Planting Material, APS, Saint Paul, 1989, p.45-49.

6. Hedges, F. A bacterial wilt of the bean caused by Bacterium flaccumfaciens nov. sp. Science, 55: 433-434, 1922.

7. Hedges, F. Bacterial wilt of beans (Bacterium flaccumfaciens Hedges), including comparisons with Bacterium phaseoli. Phytopathology, 16: $1-22,1926$. 
8. Leite Júnior, R.P.; Meneguim, L.; Behlau, F.; Rodrigues, S.R.; Bianchini, A. Ocorrência de Curtobacterium flaccumfaciens subsp. flaccumfaciens em feijoeiro no Paraná e Santa Catarina. Fitopatol. Bra., 26: 303-304, 2002.

9. Maringoni A.C.; Rosa, E.F. Ocorrência de Curtobacterium flaccumfaciens pv. flaccumfaciens em feijoeiro no Estado de São Paulo. Summa Phytopathol., 23: 160-162, 1997.

10. Maringoni, A.C.; Camara, R.C.; Souza, V.L. Semi-selective culture medium for Curtobacterium flaccumfaciens pv. flaccumfaciens isolation from bean seeds. Seed Sci. Technol., 34: 117-124, 2006.

11. Mizuno, A. Studies on specific detecting methods of two plan pathogenic bacteria. Res. Bull. Plant Prot. Serv. Jpn., $\mathrm{n}^{\circ}$ 15, 64-140, 1998.

12. Mizuno, A.; Kawai, A. Studies on the diagnosis of foreign bacterial diseases of quarantine significance, VI: Curtobacterium flaccumfaciens pv. flaccumfaciens. Res. Bull. Plant Prot. Serv. Jpn, no 29, 27-36, 1993.

13. Saettler, A.W.; Perry, S.K. Seed-transmitted bacterial diseases in michigan navy (pea) beans, Phaseolus vulgaris. Plant Dis. Rep., 56: 378-381, 1972.
14. Schaad N.W.; Forster, R.L. Detection of Xanthomonas campestris pv. translucens in wheat. In: Saettler, A.W.; Schaad, N.W.; Roth D.A. (ed). Detection of Bacteria in Seed and Other Planting Material. APS, Saint Paul, 1989, p.41-44.

15. Schuster, M.L.; Sayre, R.M. A coryneform bacterium induces purplecolored seed and leaf hypertrophy of Phaseolus vulgaris and other leguminosae. Phytopathology, 57: 1064-1066, 1967.

16. Tegli, S.; Sereni, A.; Surico, G. PCR-based assay for the detection of Curtobacterium flaccumfaciens pv. flaccumfaciens in bean seeds. Lett. Appl. Microbiol., 35: 331-337, 2002.

17. Thomas W.D.; Graham, R.W. Bacteria in apparently healthy pinto beans. Phytopathology, 42: 214-215, 1952.

18. Uesugi, C.F.; Freitas, M.A.; Menezes, J.R. Ocorrência de Curtobacterium flaccumfaciens pv. flaccumfaciens em Goiás e no Distrito Federal. Fitopatol. Bra., 28: 324, 2003.

19. van Vuurd, J.W.L.; van den Bovenkamp, G.W. Detection of Pseudomonas syringae pv. phaseolicola in bean. In: Saettler, A.W.; Schaad, N.W., Roth, D.A. (ed.). Detection of Bacteria in Seed and Other Planting Material. APS, Saint Paul, 1989, p.30-40. 